
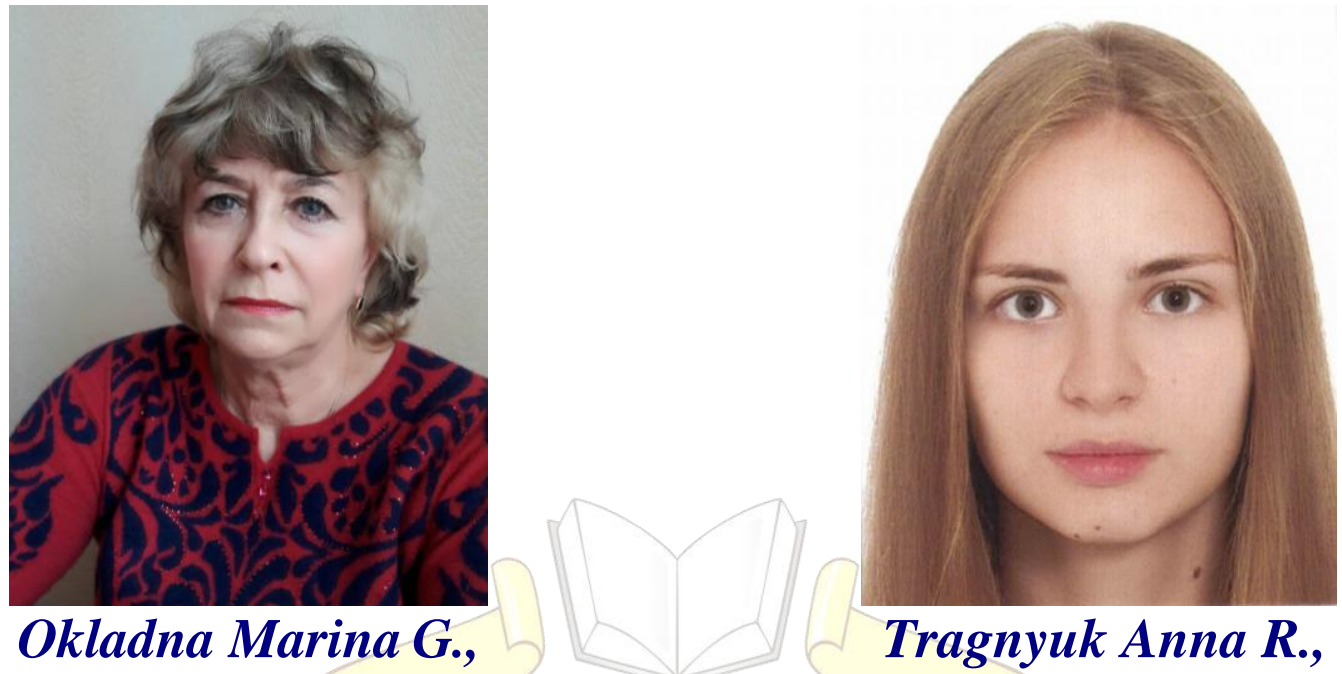

PhD in Historical Sciences, Associate Professor, 3rd year Student of the Institute of the Personnel

Associate Professor of Department

of Theory of State and Law, Training Instute for the Bodies of Justice

Yaroslav Mudryi National Law University,

Ukraine, Kharkiv

e-mail:maryokl1@gmail.com

ORCID 0000-0003-4585-7596

\title{
THE «EUROPEAN SOCIAL MODEL»: PROBLEMS OF COMPREHENSION
}

In this article we are exploring the phenomenon of European social integration and thereby creating the basics which are necessary to answer the questions: what is the European social model, how is it related to the national models of the social state, and how does the economic integration in the EU affect it nowadays.

Keywords: European social model; social state; social policy; solidarity; social integration; European Union.

Окладна М. Г., Трагнюк А. Р. «Свропейська соціальна модель»: проблеми осмислення.

Досліджено феномен свропейської соціальної інтеграції й тим самим визначено основи, необхідні для відповіді на питання: щу являють собою Європейська соціальна модель, яким чином вона співвідноситься з начіональними моделями сочіальної держави, який вплив на неї здійснює економічна інтеграчія в СС на сучасному етапі.

ЄС здійснював сочіальну політику на всіх етапах інтеграції, однак зміст і форми ії реалізації змінювалися відповідно до потреб $i$ бачення місия $i$ ролі наднаціональних інститутів у здійсненні сочіальної функиії. На сьогодні склалася європейська соціальна модель, яка увібрала кращі досягнення національних моделей соиіальної державності й функиіонує на основі розвинутого соціального права ЄС. Реалізуючи соціальну політику, ЄС діє відповідно до принщипів субсидіарності й пропориійності, поділяючи відповідальність за здійснення сочіального захисту з урядами держав-членів. Діяльність інститутів СС в рамках сочіальної політики має координуючий, доповнюючий $і$ стимулюючий характер. $У$ сфері права сочіального забезпечення йде прочес поступового зближення національного законодавства. Гармонізація соичіального законодавства держав-членів має обмежений 
характер і зводиться переважно до запровадження мінімальних сочіальних стандартів, які не повинні перешкоджати створенню і розвиткові малих і середніх підприємств. Фінансова криза негативно позначилася на соціальній політиці $\epsilon$. Заходи начіонального $i$ надначіонального рівнів влади, щзо спрямовані на вихід з неї, передбачають не лише зміну моделей сочіальної державності на національному рівні, але й оновлення ESM. Разом із тим повної відмови від здобутків у соціальній сфері не відбудеться, оскільки це завдасть суттєвої шкоди інтеграчії.

Ключові слова: Європейська соціальна модель; соціальна держава; соціальна політика; солідарність; соціальна інтеграція; Свропейський Союз.

Introduction. The social aspect of the European Communities has been existing since the launch of European integration. In so doing, since the economic integration at the beginning was an absolute priority and was supposed to contribute to the formation of an effective internal market of the Community, the role of social policy was insignificant. However, over the past decades, the importance of social policy and the implementation of socio-economic rights have been grown substantially in the eyes of EU citizens. Nowadays the problem of building a European social model is defined as one of the main priorities of the integration process. As a consequence, the social dimension of European integration is being paid more and more attention.

Analysis of the recent research. There are some aspects of the problem of the acception of the social statehood, the development of the European social model, the disclosure of its relationship with the national model of the social state [1-3], and also the peculiarities of the EU social policy at the present stage of the development of the integration process [4-7]. All of these questions were raised in the domestic researches. However, there is still no comprehensive study of features of the development of the European Union's social policy. Consequently, the purpose of this article is to analyze a complex of questions which are related to the definition of trends in the development of the European social model it the 21 st century.

Main statement. Integration is usually defined as a phenomenon of the political development of Europe since the second half of the 20th - until the beginning of the 21 st century, which determines the current state of international relations. It is possible to explain the preconditions of its origin, regularities and development prospects only by resorting and analyzing all components of the process 
of integration, such as: economic, political, legal, military, cultural, civilizational and social. However, if the problems of economic, political and legal integration in our the domestic literature were paid enough attention [8-11], for the question of the formation and implementation by the European Union its own social policy still remains insufficiently shown for us, and it gives relevance to the research of this problem now.

The first steps in establishing the sociality of the statehood of Europe happened between 1920s and 1930s, but its constitutional formulation basically took place after the Second World War. From the very beginning, each country was forming its own system of social protection, which were based on specific national conditions and in accordance with the prevailing ideology, the alignment of political forces and in accordance with the requirements of time. The existence of several rather different social state models ${ }^{1}$ in Europe that interact in a variety of ways with civil society and market economies made the tasks of harmonizing the social policies of European states extremely difficult to achieve.

The situation became more complicated, after the creation of the European Coal and Steel Community (ECSC) (1951), which marked the formation of integration process. We have to admit that from the outset, European integration had created a constitutional asymmetry between policies promoting market efficiencies and policies promoting social protection and equality. National welfare states are legally and economically constrained by European rules of economic integration, liberalization and competition law, whereas efforts to adopt European social policy are politically hampered by the national goodwill states diversity, differing not only in economic development levels [14]. As a consequence, economic policies were progressively Europeanized while social protection policies remained at the domestic level.

\footnotetext{
${ }^{1}$ Gradually formed four models covering four geographic areas: Nordic countries (Denmark, Finland and Sweden, plus the Netherlands), Anglo-Saxon countries (Ireland and the United Kingdom), Continental countries (Austria, Belgium, France, Germany and Luxembourg), Mediterranean countries (Greece, Italy, Portugal and Spain) [12, c. 375-376]. These structural differences between different national social models have high political salience. They correspond to fundamentally differing social philosophies which can be roughly equated with the social philosophies and the postwar dominance of «liberal», «christian democratic» and «social democratic» political parties [13].
} 
The process of shaping the European social policy was complicated by another problem. In the mid-1950s European welfare states were more similar (they were the Bismarck model of work-based social insurance) than they became during the following decades. Thus, harmonization would not have been hopeless. However, because of the inconsistency of the positions of the ECSC member states (the Original Six) during the development of the Treaty establishment of the European Economic Community, the social sphere was not included to the process of integration. As a result, national social security systems began to differ structurally. Their heterogeneity increased dramatically in the 1970s with the accession to the Original Six of Denmark, Britain and Ireland (non-Bismarckian welfare states).

The social integration was not part of the original grand design for Europe, blueprints for an integrated European society being wholly absent. Yet the language and terminology for incipient forms of social integration can be traced back to the discussions around harmonization surrounding the drafting of the Treaty of Rome $[15$, p. 122]. Thus, in the Treaty of the EEC, there were first steps for moving social policy from the sphere of ideology to a practical level. Articles 193-198 of the Treaty established an Economic and Social Committee with consultative status, Art. 122 provided us with the info that the Commission in its annual report to the Assembly should include a special chapter on the development of the social situation in the Community, also Art. 123 was founded by the European Social Fund, which eventually became a real financial lever for implementing social initiatives; Art. 51 was devoted to the legal regulation of the social security of migrant workers. The details of these provisions were further elaborated at the level of the EU Council regulations.

At the stage of accelerating the development of social statehood (1960-1975) it is a significant expansion of its capabilities at the level of European states, which caused the establishment of minimum social standards that, however, did not become universal, below the countries that recognize the human right to a decent life, cannot descend [16]. In general, the functioning of the social state during this period showed that it was affirmation which was based not only on the will of political leadership, 
but also on the fundamental structural changes in society, and therefore the social state had become regarded as a central element of society in the West. It is gradually becoming apparent that there is no contradiction between a social state and a market economy [1-2] which could not be eliminated - this conclusion was confirmed by the gradual introduction by the national governments of the model of a social market economy.

In 1972, a summit took place in Paris, where the problem of formation of the social policy of the European Community was raised as an independent direction of the integration process, which contributes in a certain way to the economic integration.

However, despite the adoption of such important documents as the European Social Charter [17] (1961), which proclaimed social rights, established the control mechanism which was designed to guarantee compliance by participating governments, and the Program of Social Action (1972-1974), during this period any noticeable progress in an implementation of the social policy in the European Communities was made. Cause of the position of France, Germany and the UK delegation the powers that are necessary for the formation at the supranational level a full-fledged social policy never happened. Moreover, after 1977 and by the mid1980 s, the process of issuing directives on social problems was gradually almost stopped, and the implementation of the documents which were already adopted was often blocked. This is explained by the fact that social policy was an instrument of strategic realization by the state one or another welfare model. The existence of several models of a social state in Europe which interacted with civil society and market economy in different ways complicates the task of the harmonization of the social policies of the Member States, as a consequence in this period they insisted on their own, without involving supranational structures, implementation of a social function. Starting from 1975 the stage of slowdown in the development of social statehood began. According to studies of J. J. Heckman, Instead of fostering the necessary adaptation and flexible responses to it increasingly rapid changes, modern European welfare states, which helped fuel economic and social progress during the 
'trente glorieuses' (the 30 years between 1945 and 1975 when Europe witnessed an unprecedented period of growth, stability and social cohesion), now often protect the status quo [18].

Non-synchronization of the national and pan-European process of the development of social policy has been observed for a long time. Construction of the one social space intensified in the second half of the 1980's. This was linked to the need for broad social support of the integration process, which had entered the level of the creation of the EU. The social policy of EU was recognized as one of the key instruments of integration after the adoption of the Single European Act (1986). Since that time, European Communities took the position of a new type of a social and political civilization, the basis of which was the democracy of the European model, socially oriented to the market economy, legal and social state.

The SEA had entered the agenda for the formation of a single social space. It slightly expanded the competence of supranational institutions in a social sphere (while respecting the principle of subsidiarity [19]), but it managed to violate the principle of unanimity in resolving issues, related to the safety and health of workers. Another innovation had become to the recognition of the role of social partners as indispensable actors in life communitarian social policy.

During the session of the European Council in Hanover (1988) it was indicated that there is a reliance of the implementation of the program for the creation of a single internal market on social dimension. In September of that year, the European Commission prepared a document that listed the possible measures of the European Union Communities in the social sphere (but did not specify the terms of their implementation).

The adoption of the Community Charter of Fundamental Social Rights of Workers (Social Charter) (1989), which consolidated the 12 basic rights, was an important step towards the formation of a European social model. The Charter, which has not legal, but political character, did not expand the competence of the European Communities in the social sphere. However, an attempt was made to specify the content of the European social model. But the implementation of the provisions of the 
Charter was impossible without amending the original sources with the rights of the European Community, which necessitated their updating.

As a result, on the 21st of November, 1990 the European Parliament adopted a decision according to which the Commission during the development of any legislative documents packages had to take into account a social policy.

In the early 1990's, the European Communities clashed with a number of problems in the social sphere, among which the main place was occupied by two of them:

- the expansion of the competence of EU institutions, which would allow them to be effective to the implement measures within the framework of realization the social functions by national governments;

- realization of principles of convergence and harmonization of national systems, social protection (it is difficult to realize this task, since it prevailed the idea that Europe cannot and should not have a strategy for national reforming the labor market and social policies. It is up to each national government to design and implement its own strategy [12, p. 386]).

Although there were misunderstandings between Member States in views both about the adoption of social policy and its content, the vast majority of them (except for Great Britain and Ireland) showed a desire to bring nationality social models in line with the model, which was named European Social Model (ESM).

The idea of a European Social Model was proposed in the early 1980 by the President of the European Commission Jacques Delors to distinguish Europe from the United States [20, p. 288]. Wickham (2002) stated that the main difference between the United States and Europe was that Europeans have social rights [21]. According to some authors, the frequent references to the European Social Model were even used to conceal the fundamental neoliberal character of the European integration process [22, p. 2].

However, in our opinion, implementation and rather successful functioning of the ESM is a clear indication of the commitment of the EU and its member states to the European humanitarian values, common interests and human rights, as well as 
intentions to achieve the balance between economic growth and social fairness. During the creation of the ESM, European governments were trying to make a significant improve welfare, to raise the level of economic development of the EU and each Member State, and also to ensure an equitable distribution of public wealth.

The extent of the political integration of the Community is determined by the scope (how many policies?) and level (how deep?) of amalgamation between the member states [23]. In the early 1990's Member States were aware that they have a need to expand the integration into the political and social spheres. This decision was connected with that, according to Fritz W. Scharpf, the advance of economic integration has greatly reduced the capacity of member states to influence the course of their own economies and to realize self-defined sociopolitical goals. In short, compared to the repertoire of policy choices that was available two or three decades ago, European legal constraints have greatly reduced the capacity of national governments to influence growth and employment in the economies for whose performance they are politically accountable. It is no wonder, therefore, that countries and interest groups that had come to rely on social regulations of the economy and generous welfare-state transfers and services are now expecting the European Union to protect the «European Social Model» and thus to re-establish the constitutional parallelism of economic («market making») and social protection («market correcting») interests and policy purposes that had existed at the national level before the take-off of economic integration [14, p. 648-649].

We have to admit the fact that the creation of ESM was evaluated indistinct: some authors believed that the Europeanisation of social policy is a 'cornerstone' of the policy package and that Lisbon represents a genuine turn to the social in EU thinking, the others insisted on, that the core of the project is economic union or integration more widely, and that the attention turns to social policy only because it is necessary to cushion socio-politically the impact of the single market and associated change [24, p. 15-16].

The improvement of social policy of united Europe is related to the entry into the force of Maastricht Treaty on European Union [25], which complemented the 
Treaty establishing the European Economic Community with articles VIII «Social Policy, Education, Vocation Training and Youth» i XIV «Economic and Social Cohesion», and also applications - Agreement on Social Policy and Protocol on Social Policy. Monica Threlfall notes this represented a gain in Community competencies, as the issue of social exclusion became a legitimate field of concern, and aspects of social legislation were facilitated by qualified majority voting (QMV) in the Council of Ministers, such as equality between men and women in employment [26, p. 276].

An essential innovation was introduction of the Open Method of Coordination (OMC) in order to protect and promote Social Europe [27-29]. The Lisbon Summit then introduced the generic label of OMC and resolved to apply it not only to issues of education, training, R\&D and enterprise policy, but also to «social protection» and «social inclusion». The Open Method was most fully specified for the European Employment Strategy (EES) which came to be known as the «Luxembourg Process» $[14$, p. 652-653]. Using the Open Method of Coordination should have helped to restore the principle of solidarity in the EU, because solidarity is mostly limited to national borders. The European Commission insisted on this demand [30].

The process of the development of the Maastricht Treaty was accompanied by the study of problems related to the introduction of the European social policy, as results of which had been prepared «Growth, Competitiveness, Employment: The Challenges and Ways Forward into the 21st Century - White Paper» [31] (1993), «Green Paper - European social policy - Options for the Union» [32] (1993) i «European Social Policy - A Way Forward for the Union. A White Paper» [33] (1994). Therefore, at the end of the 20th century holding a single social policy became a vital element which was necessary for strengthening the internal ties within the EU and the formation of a European identity. Competences which were granted to communist institutions, policy of social partnerships they are realizing on an EU scale, different forms and levels of cooperation lead to the increase of the role of supranational regulation, enforcement of the principle of the primacy of EU law over the relevant ones in national law branches. 
The Treaty of Amsterdam (1997) marked another milestone in the status of social policies in general, as they were bolstered by a set of civil and human rights1.

The Amsterdam Treaty gave an impulse to the intensification of social policy and harmonization of national social legislation. The social EU policy, from this moment means the development of the concept of EU activity in the social sphere; detection of determinants that guarantee the quality of life, steady development, competitiveness and others most important indicators of the full potential growth of the EU; creation of a comprehensive system of events and programs, social technologies that provide social stability, overcome internal contradictions and the struggle between different social forces; the formation of the mechanism ensuring EU interests and solving relevant tasks in the social sphere; forecasting of the EU social future, ways of social development a new integrated society, the possible consequences of this complex and largely contradictory process [4, p. 19].

In this way, the Maastricht and Amsterdam treaties and the «Program of Social Action» defined the legal basis of the EU social policy, provided the legal conditions for the implementation of the rights which were proclaimed in the Charter and had shown the awareness of Europeans about the need to pay attention to the problems which determine the meaning of the concept of «social dimension». The social integration has progressed through convergence of policies, policy outcomes and social trends, as well as through harmonization and approximation of laws, to the point where a series of «single social areas» have been created in which citizens experience living or working in the EU as if they were in a single country [26, p. 274].

The concept of «social dimension» focuses on the social implications of each direction of the EU policy, and the activities of the Union are shown through the prism of the social problems existing within its framework [34]. Within the geographical boundaries of the EU the social dimension is expressed throughout the

\footnotetext{
${ }^{1}$ Monica Threlfall notes: «The status of gender equality was raised, to become a chief goal of the EU (Art. 2), and positive action to advance sex equality was allowed (Art. 141). A new article with wide-reaching implications banned discrimination on the grounds of sex, racial or ethnic origin, religion or belief, disability, age and sexual orientation (Art. 6A, later consolidated as 13). It allowed the Community to take action to combat discrimination, albeit only via unanimity in the Council of Ministers. This marked a clear shift by the EU towards addressing issues of race and ethnicity, and by implication, the treatment of new immigrants and foreigners» [26, p. 277-278].
} 
creation of a single social space, a category, which means the space, in accordance with EU law, the social policy of the EU is being implemented.

An update of the paradigm of social development and social policy in the EUTOccurs consistently and gradually, taking into account the previous achievements of Member States and the Union as a whole, existing national traditions, based on a deep analysis of the current state and prospects for its development. As a result, the level of centralization of social policy at the supranational level is determined by the nature of the problems that face the integration association, peculiarities of the corresponding stage of development.

Since the modern stage in the development of social statehood in Europe occurs under the powerful influence of the requirements of globalization and regional integration, the ability of national powers form and realize their own social policy to independently is gradually decreasing now. Despite this tendency caused by objective factors national state is trying to maintain its own legitimacy and functionality, which prompts it to adapt the national one strategies of social and economic development to global dimensions. In addition, the implications of the two rounds of eastward enlargement of the 2000s do not merely complicate but fundamentally preclude any prospect of major re-regulatory social policy [35; 36, p. 754].

The Contradiction of economic and social rights, as well as blurring social standards between the «old» and «new» members of the Union threaten the EU with the process of disintegration, forcing the Union's institutions to respond to the problem. The European Parliament in 2008 approved a special resolution on challenges to collective agreements in the EU (2008/2085) INI)), in which he emphasized that it was unacceptable to give preference to economic rights over social rights [37]. Parliament also appealed to national governments to develop measures that would limit social dumping between Member States of the EU.

About the tendency to strengthen the role of communitarian institutions in the EU and the implementation of social policy indicates the expansion of their functions in this particular area. Nowadays they are engaged in developing a strategy for social development of the EU, framework programs for social action and general 
guidelines; holding researches on the problems of promoting social dialogue; analysis of the situation and control over observance of the agreed course and execution of the taken decisions basically in Member States, and, where necessary, the development of recommendations of national governments; coordination of actions which are made by Member States; development supranational regulations on social issues and control over the implementation process in national legislation, etc.

J. M. Barroso, the Chairman of the European Commission, at the end of the first term of his chairmanship, tried to demonstrate commitment to the idea of security of the Social rights: in a message to the European Parliament (2009), he noted that social rights, is particular the right to strike and to associate, have a fundamental value for the European model of society [38]. However, financial (2008) and demographic crises hinder expansion social programs of both individual Member States and the EU as a whole. The president of the European Central Bank, Mario Draghi, stated in an interview with the Wall Street Journal in February 2012 that the there may have been a time when Europe could afford to maintain a comprehensive system of welfare protection, but given the economic problems faced by many European countries, as highlighted by the current crisis, this is no longer the case. The ECB president, furthermore, noted that austerity coupled with structural change is the only option for economic renewal in Europe [22, p. 1-2]. Therefore, it is not surprising that in the expert environment has been put forward the conclusion that the overall thrust of European integration, especially under the two Barroso Commission cabinets, has been largely deregulatory and (neo)liberal in nature, which suggests that the commitment to a re-regulatory 'Social Europe' of the Jacques Delors era (198594) has been all but abandoned [36, p. 753]. Expert environment was put forward by the Conclusion has been made that the general thrust of European integration, especially under the two Barroso Commission chambers, has been largely deregulatory and (neo) liberal in nature, which suggests that the commitment to a reregulation. The 'Social Europe' of the Jacques Delors era (1985-94) has been all but abandoned [36, p. 753].

Despite the pessimistic conclusions, there is still some progress in solving the 
issue of the ESM at the present stage. Lisbon Treaty details the goals of the Union's social policy; provides the binding force of the Charter of Fundamental Rights of the European Union that fixes the basic social and labor rights of EU citizens; relates social policy to the shared competence of the EU and the Member States; allows EU institutions to set minimum social and labor standards by harmonizing them, which does not deprive national governments of the right to develop and introduce additional requirements for raising social standards for the protection of the population [39].

In March 2010, the European Commission developed and approved a new strategy for economic development «Europe 2020: A European Strategy for Smart, Sustainable and Inclusive Growth» [40]. One of the basic tasks of the Strategy is to ensure the overall growth under which the Commission understands the economy as a high degree of the population employment inside the country, which strives to economic, social and territorial association. Comprehensive growth of the economy should provide people with new opportunities through high level of employment, investments in knowledge and skills, combating poverty and improvement of the labor market, training and social protection, which together can make a contribution in building more socially homogeneous society. It is really necessary for the results of economic growth to be distributed throughout the $\mathrm{EU}$ in order to enhance the territorial unity.

Conclusion. The analysis of the content and directions of the evolution of social policy of The European Union give us a chance to make some conclusions.

1. The assertion of social statehood in Western Europe, its agreement with requirements of market economy in general terms happened in the middle of the twentieth century. However, at the supranational level the process of introducing social policy as an independent direction of the integration process stretched for almost forty years throughout the inhibition of this process by national governments.

2. The EU was implementing social policies at all stages of the integration, however, the content and forms of its realization changed in accordance with the needs and the vision of the place and the role of supranational institutions in the 
implementation of the social function. Nowadays a European social model was emerged. It absorbed the best achievements of national models of social statehood and functions on a basis of social rights which were developed in the EU.

3. While implementing social policy, the EU acts in accordance with the principles of subsidiarity and proportionality, sharing responsibility for implementation social protection with the governments of the Member States. The activity of the EU Institutions in social policy has a coordinating, complementary and stimulating nature.

4. In the field of social welfare there is a gradual process of convergence of national legislation. Harmonization of social legislation of the Member States is limited and is reduced to the introduction of minimum social standards that should not prevent the creation and development of small and medium enterprises.

5. The financial crisis had a negative impact on EU social policy. Measures of national and supranational levels of government are aimed to escape from it, also it is predicting not only the change of models of social statehood on national level, but also an update to the ESM. However, the complete refusal of achievements in the social sphere will not take place, as this will cause significant damage to the integration process.

\section{Список літератури:}

1. Яковюк I. В. Соціальна і правова держава: співвідношення понять. Державне будівництво та місиеве самоврядування. 2001. Вип. 1. С. 99-105.

2. Яковюк I. В. Про обсяг поняття «соціальна держава» (на основі порівняльного аналізу моделей ФРН і України). Право України. 1998. № 11. С 26-28.

3. Окладна М. Г., Головащенко О. С. Свропейський соціальний простір: проблеми формування. Юридичний науковий електронний журнал. 2015. № 3. С. 12-14.

4. Окладна М. Г., Яковюк І. В. Соціальна політика Свропейського Союзу: становлення і розвиток. Харків: ТОВ «Оберіг», 2016. 40 с. (Серія «Наукові доповіді», вип. 19).

5. Окладна М. Г., Якименко Х. С. Соціальна політика Свропейського Союзу: уроки для України. Актуальні проблеми сучасного міжнародного права: зб. наук. ст. за матеріалами I Харк. міжнар.-прав. читань, присвяч. пам'яті проф. М. В. Яновського і В. С. Семенова (м. Харків, 27 листоп. 2015 р.): у 2 ч. Харків, 2015. Ч. 1. С. 193-199.

6. Вітте Л. Європейська соціальна модель і соціальна згуртованість: яку роль відіграє ЄС? Київ: Заповіт, 2006. 44 с.

7. Яковюк I. В. Реалізація соціальної функції держави в умовах європейської інтеграції. Державне будівництво та місиеве самоврядування. 2004. Вип. 7. С. 40-48.

8. Історія європейської інтеграції від Римської імперії до Європейського Союзу: монографія / за ред. І. В. Яковюка. Київ: Ред. журн. «Право України», 2012. 208 с.

9. Байдін Ю. В. Державний суверенітет і його межі в умовах європейської інтеграції 
(питання теорії): дис. ... канд. юрид. наук: 12.00.01. Харків, 2012. 245 с.

10. Якименко Х. С. Свропейський союз: правова природа об'єднання: дис. ... канд. юрид. наук: 12.00.01. Харків, 2009. 229 с.

11. Сало В. І. Внутрішні функції держави в умовах членства в Свропейському Союзі: дис. ... канд. юрид. наук: 12.00.01. Харків, 2008. 220 с.

12. André Sapir. (2006). Globalisation and the Reform of European Social Models. Background document for the presentation at ECOFIN Informal Meeting in Manchester. Journal of Common Market Studies. Vol. 44. No 2. P. 369-90.

13. Huber, E. and Stephens, J. D. (2001). Development and Crisis of the Welfare State. Parties and Policies in Global Markets. Chicago: University of Chicago Press.

14. Fritz, W. Scharpf. (2002). The European Social Model: Coping with the challenges of diversity. Journal of Common Market Studies. Vol. 40. No 4. P. 645-670. DOI: 10.1111/14685965.00392.

15. Monica Threlfall. (2003). European Social Integration: Harmonization, Convergence and Single Social Areas. Journal of European Social Policy. 13: 121. DOI: 10.1177/0958928703013002002.

16. Яковюк І. В. Виникнення та розвиток концепції соціальної держави. Вісник Акад. прав. наук України. 2001. № 2. С. 24-29.

17. Яковюк I. В. Розвиток концепції соціально-економічних прав як передумова формування соціальної держави. Проблеми законності. 1998. № 35. С. 22-27.

18. Heckman, J. J. (2002). 'Flexibility, Job Creation and Globalization: The Case of Italy'. Paper presented at the Third Millennium Colloquia organized by the Instituto di Studi Economici et per l'Occupazione, Venice, 2-3 December.

19. Яковюк I. Субсидіарність як принцип взаємовідносин національних держав i Свропейського Союзу. Вісник Акад. прав. наук Украӥни. 2004. № 4 (39). С. 22-30.

20. Wincott, Daniel. (2003). 'The Idea of the European Social Model: Limits and Paradoxes of Europeanization, in Kevin Featherstone and Claudio Radaelli, eds., The Politics of Europeanization. Oxford: Oxford University Press. P. 279-302.

21. Wickham, James. (2002). 'The End of the European Social Model: Before It Began?' Employment Research Centre, Department of Sociology. Trinity College Dublin.

22. Hermann, Christoph (2013). Crisis, structural reform and the dismantling of the European Social Model(s), Working Paper, Institute for International Political Economy Berlin, No. 26/2013.

23. Delhey, Jan (2004). European social integration: From convergence of countries to transnational relations between peoples WZB Discussion Paper. URL: https://www.ssoar.info/ssoar/bitstream/handle/document/11758/ssoar-2004-delhey-european_social _integration.pdf? sequence $=1$.

24. Daly, Mary. (2007). Whither EU Social Policy? An Account and Assessment of Developments in the Lisbon Social Inclusion Process. Journal of Social Policy 37, 1-19. Doi:10.1017/S0047279407001468.

25. Treaty on European Union, as signed in Maastricht on 7 February 1992. URL: https://europa.eu/european-union/sites/europaeu/files/docs/body/treaty_on_european_union_en.pdf.

26. Threlfall, Monica. (2007). The Social Dimension of the European Union. Global Social Policy 7, 3, 271-293. Doi: 10.1177/1468018107082235

27. Susana Borra's and Kerstin Jacobsson. (2004). The open method of co-ordination and new governance patterns in the EU. Journal of European Public Policy. 11:2 April: 185-208. DOI: $10.1080 / 1350176042000194395$.

28. De la Porte, C. (2011). 'Principal-Agent Theory and the Open Method of Co-ordination: The Case of the European Employment Strategy'. Journal of European Public Policy 18(4): 485503. DOI: $10.1080 / 13501763.2011 .560071$.

29. De la Porte, C., Pochet, P. (eds). (2012). Why and how (still) study the Open Method of Co-ordination (OMC)? Journal of European Social Policy 23(3): 336-349. DOI: 


\section{$10.1177 / 0958928711433629$}

30. European Commission. (1994). 'European Social Policy - A Way Forward for the Union: A White Paper', COM (94) 333, final.

31. Growth, Competitiveness, Employment: The Challenges and Ways Forward into the 21st Century. URL: http://aei.pitt.edu/1139/1/growth_wp_COM_93_700_Parts_A_B.pdf.

32. Green Paper - European social policy - Options for the Union. URL: https://publications.europa.eu/en/publication-detail/-/publication/434c867b-615c-45bc-950b2512022c2e8b/language-en.

33. European Social Policy - A Way Forward for the Union. A White Paper. URL: http://aei.pitt.edu/1118/1/social_policy_white_paper_COM_94_333_A.pdf.

34. Stephan Leibfried. (1994). The Social Dimension of the European Union: En Route To Positively Joint Sovereignty? Journal of European Social Policy. Vol 4, Issue 4, P. 239-262. DOI: $10.1177 / 095892879400400401$.

35. Vaughan-Whitehead, D. EU Enlargement versus Social Europe? The Uncertain Future of the European Social Model, Edward Elgar, Cheltenham, 2003, XVII + 567 p.

36. Amandine Crespy, Georg Menz. Commission Entrepreneurship and the Debasing of Social Europe Before and After the Eurocrisis. JCMS 2015 Vol. 53. No 4. P. 753-768. DOI: $10.1111 /$ jcms.12241.

37. Sionaidh Douglas-Scott. (2011). The European Union and Human Rights after the Treaty of Lisbon. Human Rights Law Review. 11:4. P. 645-682. DOI:10.1093/hrlr/ngr038.

38. Position Paper from the European Federation of Building and Woodworkers on fundamental social rights in the European Union. URL: http://www.efbww.org /pdfs/FSR\%20GB\%20new.pdf.

39. Treaty of Lisbon amending the Treaty on European Union and the Treaty establishing the European Community, signed at Lisbon, 13 December 2007. URL: http://eurlex.europa.eu/legal-content/EN/TXT/?uri=celex\%3A12007L\%2FTXT.

40. European Commission/ (2010). Europe 2020: A European Strategy for Smart, Sustainable and Inclusive Growth, European Commission, Brussels, COM(2010)2020.

\section{References:}

1. Yakoviuk, I.V. (2001). Sotsialna i pravova derzhava: spivvidnoshennia poniat. Derzhavne budivnytstvo ta mistseve samovriaduvannia, issue 1, 99-105 [in Ukrainian].

2. Yakoviuk, I.V. (1998). Pro obsiah poniattia «sotsialna derzhava» (na osnovi porivnialnoho analizu modelei FRN i Ukrainy). Pravo Ukrainy, 11, 26-28 [in Ukrainian].

3. Okladna, M.H., Holovashchenko, O.S. (2015). Yeyropeiskyi sotsialnyi prostir: problemy formuvannia. Yurydychnyi naukovyi elektronnyi zhurnal, 3, 12-14 [in Ukrainian].

4. Okladna, M.H., Yakoviuk, I.V. (2016). Sotsialna polityka Yevropeiskoho Soiuzu: stanovlennia i rozvytok. Kharkiv: TOV «Oberih». (Seriia «Naukovi dopovidi», issue 19) [in Ukrainian].

5. Okladna, M.H., Yakymenko, Kh.S. (2015). Sotsialna polityka Yevropeiskoho Soiuzu: uroky dlia Ukrainy. Aktualni problemy suchasnoho mizhnarodnoho prava: proceedings of the I International Scientific and Practical Conference, Kharkiv, 27 lystop. 2015 r.: u 2 ch. Kharkiv, ch. 1, 193-199 [in Ukrainian].

6. Vitte L. (2006). Yevropeiska sotsialna model i sotsialna zghurtovanist: yaku rol vidihraie YeS? Kyiv: Zapovit [in Ukrainian].

7. Yakoviuk, I.V. (2004). Realizatsiia sotsialnoi funktsii derzhavy v umovakh yevropeiskoi intehratsii. Derzhavne budivnytstvo ta mistseve samovriaduvannia, issue 7, 40-48 [in Ukrainian].

8. Yakoviuka, I.V. (Ed.). (2012). Istoriia yevropeiskoi intehratsii vid Rymskoi imperii do Yevropeiskoho Soiuzu. Kyiv: Pravo Ukrainy [in Ukrainian].

9. Baidin, Iu.V. (2012). Derzhavnyi suverenitet i yoho mezhi v umovakh yevropeiskoi intehratsii (pytannia teorii). Candidate's thesis. Kharkiv [in Ukrainian].

10. Yakymenko, Kh.S. (2009). Yevropeiskyi soiuz: pravova pryroda obiednannia. 
Candidate's thesis. Kharkiv [in Ukrainian].

11. Salo, V.I. (2008). Vnutrishni funktsii derzhavy v umovakh chlenstva v Yevropeiskomu Soiuzi. Candidate's thesis. Kharkiv [in Ukrainian].

12. Sapir, André. (2006). Globalisation and the Reform of European Social Models. Background document for the presentation at ECOFIN Informal Meeting in Manchester. Journal of Common Market Studies. Vol. 44, 2, 369-90.

13. Huber, E. and Stephens, J.D. (2001). Development and Crisis of the Welfare State. Parties and Policies in Global Markets (Chicago: University of Chicago Press).

14. Fritz, W. Scharpf. (2002). The European Social Model: Coping with the challenges of diversity. Journal of Common Market Studies, Vol. 40, 4. 645-670. DOI: 10.1111/14685965.00392.

15. Threlfall, Monica. (2003). European Social Integration: Harmonization, Convergence and Single Social Areas. Journal of European Social Policy, 13: 121. DOI: 10.1177/0958928703013002002.

16. Yakoviuk, I.V. (2001). Vynyknennia ta rozvytok kontseptsii sotsialnoi derzhavy. Visn. Akad. prav. nauk Ukrainy, 2, 24-29 [in Ukrainian].

17. Yakoviuk, I.V. (1998). Rozvytok kontseptsii sotsialno-ekonomichnykh prav yak peredumova formuvannia sotsialnoi derzhavy. Problemy zakonnosti, 35, 22-27 [in Ukrainian].

18. Heckman, J.J. (2002). 'Flexibility, Job Creation and Globalization: The Case of Italy' Paper presented at the Third Millennium Colloquia organized by the Instituto di Studi Economici et per l'Occupazione, Venice, 2-3, December.

19. Yakoviuk, I. (2004). Subsydiarnist yak pryntsyp vzaiemovidnosyn natsionalnykh derzhav i Yevropeiskoho Soiuzu. Visnyk Akademii pravovykh nauk Ukrainy, 4 (39), 22-30.

20. Wincott, Daniel (2003). The Idea of the European Social Model: Limits and Paradoxes of Europeanization. The Politics of Europeanization. Kevin Featherstone and Claudio Radaelli. (Eds.). Oxford: Oxford University Press, 279-302.

21. Wickham, James. (2002). The End of the European Social Model: Before It Began?. Employment Research Centre, Department of Sociology. Trinity College Dublin.

22. Hermann, Christoph. (2013). Crisis, structural reform and the dismantling of the European Social Model(s). Working Paper, Institute for International Political Economy Berlin, $26 / 2013$.

23. Delhey, Jan. (2004). European social integration: From convergence of countries to transnational relations between peoples, WZB Discussion Paper. URL: https://www.ssoar.info/ssoar/bitstream/handle/document/11758/ssoar-2004-delheyeuropean_social_integration.pdf?sequence $=1$.

24. Daly, Mary. (2007). Whither EU Social Policy? An Account and Assessment of Developments in the Lisbon Social Inclusion Process. Journal of Social Policy, 37, 1-19. Doi:10.1017/S0047279407001468.

25. Treaty on European Union, as signed in Maastricht on 7 February 1992. URL: https://europa.eu/european-union/sites/europaeu/files/docs/body/treaty_on_european_union_en.pdf.

26. Threlfall, Monica. (2007). The Social Dimension of the European Union. Global Social Policy, 7, 3, 271-293. Doi: 10.1177/1468018107082235

27. Susana Borra's and Kerstin Jacobsson. (2004). The open method of co-ordination and new governance patterns in the EU. Journal of European Public Policy. 11:2 April 2004, 185-208. DOI: $10.1080 / 1350176042000194395$.

28. De la Porte, C. (2011). Principal-Agent Theory and the Open Method of Co-ordination: The Case of the European Employment Strategy. Journal of European Public Policy, 18 (4), 485503. DOI: 10.1080/13501763.2011.560071.

29. De la Porte, C., Pochet, P. (Eds). (2012). Why and how (still) study the Open Method of Co-ordination (OMC)? Journal of European Social Policy, 23(3), 336-349. DOI: $10.1177 / 0958928711433629$

30. European Commission. (1994). European Social Policy - A Way Forward for the Union: 
A White Paper, COM (94) 333, final.

31. Growth, Competitiveness, Employment: The Challenges and Ways Forward into the 21st Century. URL: http://aei.pitt.edu/1139/1/growth_wp_COM_93_700_Parts_A_B.pdf.

32. Green Paper - European social policy - Options for the Union. URL: https://publications.europa.eu/en/publication-detail/-/publication/434c867b-615c-45bc-950b2512022c2e8b/language-en.

33. European Social Policy - A Way Forward for the Union. A White Paper. URL: http://aei.pitt.edu/1118/1/social_policy_white_paper_COM_94_333_A.pdf.

34. Stephan Leibfried. (1994). The Social Dimension of the European Union: En Route To Positively Joint Sovereignty? Journal of European Social Policy, Vol 4, Issue 4, 239-262. DOI: 10.1177/095892879400400401.

35. Vaughan-Whitehead, D. (2003). EU Enlargement versus Social Europe? The Uncertain Future of the European Social Model, Edward Elgar, Cheltenham.

36. Amandine Crespy, Georg Menz. (2015). Commission Entrepreneurship and the Debasing of Social Europe Before and After the Eurocrisis. JCMS, Vol. 53, 4, 753-768. DOI: $10.1111 / \mathrm{jcms} .12241$.

37. Sionaidh Douglas-Scott. (2011). The European Union and Human Rights after the Treaty of Lisbon. Human Rights Law Review, 11:4, 645-682. DOI:10.1093/hrlr/ngr038.

38. Position Paper from the European Federation of Building and Woodworkers on fundamental social rights in the European Union. URL: http://www.efbww.org/pdfs /FSR\%20GB\%20new.pdf.

39. Treaty of Lisbon amending the Treaty on European Union and the Treaty establishing the European Community, signed at Lisbon, 13 December 2007. URL: http://eurlex.europa.eu/legal-content/EN/TXT/?uri=celex\%3A12007L\%2FTXT.

40. European Commission. (2010). Europe 2020: A European Strategy for Smart, Sustainable and Inclusive Growth. European Commission, Brussels, COM(2010)2020.

\section{осмысления.}

Окладная М. Г., Трагнюк А. Р. «Европейская социальная модель»: проблемы

Исследуется феномен европейской социильной интеграции и тем самым устанавливаются основы, необходимые для ответа на вопрос: что представляют собой Европейская социальная модель, каким образом она соотносится с национальными моделями социального государства, какое влияние на нее осуществляет экономическая интеграчия в ЕС на современном этапе.

Ключевые слова: Европейская социальная модель; социальное государство; социальная політика; солидарность; социальная интеграция: Европейский Союз.

Надійила до редколегії 12.02.2018р. 